\title{
PENGEMBANGAN SISTEM DETEKSI KELELAHAN PADA PENGEMUDI MOBIL BERBASIS SINYAL ELECTROMYOGRAPHY (EMG)
}

\author{
Sukma Firdaus, Marlia Adriana \\ Jurusan Mesin Otomotif, Politeknik Negeri Tanah Laut \\ email: sukma@politala.ac.id
}

\begin{abstract}
ABSTRAK
Peningkatan alat trasportasi khususnya kendaraan roda empat (mobil) mengakibatkan peningkatan volume kendaraan di jalan. Hal ini berdampak pada meningkatnya kemacetan. Selain kemacetan, peningkatan volume kendaraan berdampak juga pada peningkatan kecelakan lalu lintas. Salah satu penyebab kecelakan lalu lintas adalah faktor pengendaranya, yaitu kelelahan. Penelitian ini, merancang sistem pendeteksi kelelahan pengemudi, berdasarkan sinyal biologis pengemudi yaitu sinyal biologis kondisi otot lengan. Sinyal tersebut direkam dengan menggunakan metode surface EMG. Elektroda yang ditempelkan disebelah kanan lengan dihubungkan dengan penguat instrumentasi dan digitalisasi melalui unit pemproses sinyal untuk dapat disimpan kedalam komputer. Kegiatan pengambilan data dilakukan sebanyak 8 kali dengan jarak tempuh pengemudi sebesar $80 \mathrm{~km}$ dari Kota Banjarmasin menuju Kota Pelaihari. Akuisisi data menggunakan frekuensi sampling sebesar $4 \mathrm{KHz}$ dan diproses secara filter analog untuk High Pass Filter sebesar $2 \mathrm{KHz}$ dan Low Pass Filter sebesar $500 \mathrm{~Hz}$. Setelah data direkam, sinyal dilakukan proses downsampling menjadi $1 \mathrm{KHz}$. Pada proess digital, dilakukan lagi proses pemfilteran secara Low Pass Filter sebesar $500 \mathrm{~Hz}$. Proses digital selanjutnya adalah melakukan analisis pada domain frekuensi menggunakan transformasi fourier dengan memakai algoritma fast fourier transform (fft). Hasil dari transformasi fourier diidentifikasi berdasarkan nilai Mean Power Frequency (MPF). Berdasarkan hasil perhitungan MPF yang telah dilakukan, diperoleh saat awal berkendara nilai rata-rata MPF nya adalah sebesar 25,2 Hz sedangkan pada akhir berkendara bernilai sebesar 33,3 Hz. Dengan hasil ini dapat tergambarkan kondisi pengemudi pada awal mengemudi dan tidak terjadi kelelahan maka nilai frekuensi yang dominan cenderung lebih rendah jika dibandingkan dengan setelah berkendara atau saat kelelahan.
\end{abstract}

Kata Kunci: Kelelahan, Sinyal Electromyography (EMG), Ekstraksi Sinyal

\section{PENDAHULUAN}

Berkembangnya alat transportasi menurut jumlahnya memberikan dampak yang sangat signifikan, baik sektor ekonomi ataupun peningkatan status sosial seseorang. Tentunya semua orang saat ini memiliki keinginan untuk memiliki kendaraan pribadi, khususnya mobil. Sehingga memberikan dampak adanya peningkatan jumlah mobil, dan semakin nyata terlihat ketika para produsen mobil berlomba-lomba membuat mobil dengan harga jual yang lebih murah dibandingkan tahun-tahun sebelumnya. Hal ini tentunya membuat kondisi jalan raya menjadi lebih padat, karena volume jalan menjadi bertambah. Dengan bertambahnya volume jalan, mengakibatkan berbagai masalah, diantaranya kemacetan.

Kondisi jalan yang macet memiliki pengaruh yang sistemik bagi pengguna jalan, diantaranya yang paling memprihatinkan adalah membuat meningkatnya angka kecelakaan lalu lintas. Walau sebenarnya, kecelakaan mempunyai banyak faktor sebagai pennyebab terjadinya, tetapi faktor tertinggi sebenarnya disumbang oleh kesalahan si pengemudi itu sendiri. Kesalahan yang sering muncul adalah, pengemudi berada pada kondisi kelelahan tetapi masih tetap saja mengendarai kendaraannya atau akibat terlalu lama mengemudi akibat kemacetan ataupun akibat terlalu jauh dalam mengemudikan kendaraanya. Hal ini tentunya harus diantisipasi lebih awal, akan tetapi permasalah yang sering muncul bagi si pengemudi adalah tidak mengetahui dengan sebenar-benarnya kalau kondisi tubuhnya sudah mengalami kelelahan.

Kelelahan sebenarnya merupakan suatu mekanisme perlindungan dari tubuh agar tubuh terhindar dari kerusakan lebih lanjut. Maka, jika mengalami kelelahan saat mengemudi seharusnya hal yang harus dilakukan adalah beristirahat. Kondisi kelelahan setiap orang biasanya berbeda-beda, tetapi semuanya bermuara pada kehilangan efisiensi dan penurunan ketahanan tubuh serta penurunan kemampuan dalam berkonsentrasi. Konsep kelelahan dibagi menjadi subyektif, obyektif dan fisiologi. Kelelahan subyektif adalah dibedakan dengan suatu penurunan kesiagaan, konsentrasi mental, dan motivasi dan kelelahan obyektif adalah dicirikan dengan penurunan input kerja, sedangkan kelelahan fisiologi adalah dihubungkan dengan perwujudan eksternal seperti ketidakmampuan mempertahankan suatu gaya input yang diberikan, gemetar pada otot, dan kesakitan 
pada sekelompok otot tertentu yang melaksanakan kontraksi. Hal ini tentuya akan berakibat sangat fatal jika pada saat kondisi lelah tetap dipertahankan untuk mengendarai kendaraan, karena dapat membahayakan dirinya sendiri dan juga pengguna jalan lainnya [1].

Untuk dapat mengetahui lebih awal kondisi pengemudi atas kelelahannya, maka diperlukan sistem yang dapat memberitahukan kepada pengemudi terkait kondisinya. Sistem tersebut harus melibatkan pengukuran secara fisiologi tubuh untuk dapat memberikan keputuan yang akurat terhadap pengemudi. Kondisi kelelahan dapat diketahui melalui kondisi kelelahan otot salah satunya pada kondisi otot lengan, dimana otot lengan secara langsung berhubungan dengan tangan yang memegang kemudi secara terus menerus. Otot jika terus menerus bekerja dan dengan posisi yang tidak bergerak-gerak tanpa berkontraksi dan berelaksasi maka akan mengalami kondisi kelelahan (fatique), sehingga penilaian terhadap fisiologis otot dapat berpeluang dalam menilai kondisi kelelahan pengemudi. Aktifitas otot, baik itu berkontraksi maupun berelaksasi dapat dievaluasi dan direkam melalui sinyal electromygram (EMG). Sinyal EMG memiliki informasi terkait kondisi aktifitas otot, sehingga perekaman sinyal EMG dapat menjadi sebuah tools yang bisa diamati untuk mengevaluasi kelelahan pengemudi.

\section{TINJAUAN PUSTAKA}

Otot adalah sebuah jaringan konektif dalam tubuh yang tugas utamanya kontraksi. Kontraksi otot berfungsi untuk memindahkan / menggerakkan bagian bagian tubuh dan substansi dalam tubuh. Ada tiga macam sel otot alam tubuh manusia (jantung, lurik dan polos) namun yang berperan dalam pergerakan kerangka tubuh manusia adalah otot lurik (otot rangka). Otot rangka adalah jaringan peka rangsang yang diatur oleh saraf motorik somatic dalam kesatuan yang disebut syaraf motorik unit (smu). Seperti halnya syaraf - syaraf yang lain, smu juga memiliki ambang rangsang tertentu. Jika rangsang yang diberikan melewati ambangnya, maka pada syaraf tersebut akan muncul potensial aksi dan dihantarkan sebagai impuls [2].

Karakteristik sinyal EMG mempunyai amplitudo relatif kecil, yaitu berkisar $10 \mathrm{mV}$ dengan frekuensi 20 $500 \mathrm{~Hz}$, sehingga diperlukan rangkaian penguat, dan filter band pass dengan low pass filter $500 \mathrm{~Hz}$ dan high pass filter $20 \mathrm{~Hz}$. Rangkaian penguat bisa berupa differential amplifier berfungsi untuk menangkap sinyal mioelektrik dari otot untuk kemudian dikuatkan. Rangkaian ini mempunyai impedansi input yang sangat rendah sehingga dapat disiasati dengan menggunakan rangkaian instrumentation amplifier [3].

Untuk dapat menganalisa tingkat kelelahan dari otot lengan, maka sinyal EMG perlu untuk dianalisa berdasarkan parameter frekuensinya. Sinyal terlebih dahulu harus ditransformasi menggunakan Fourier. Transformasi Fourier (TF) direpresentasikan kedalam persamaan matematis seperti pada persamaan 1 . TF berjalan sesuai dengan translasi suatu fungsi dalam domain waktu kedalam fungsi dari domain frekeunsi. Hasil perhitungan dari transformasi fourier dapat dijadikan bahan dalam menganalisa sinyal EMG, karena nilai-nilai dari koefisien fourier merupakan hasil dari frekuensi-frekuensi sinus dan cosinus yang digunakan dalam TF [4].

Untuk data diskrit, TF disebut sebagai Discrite Fourier Transform (DFT). DFT direpresentasikan kedalam matematis, seperti pada persamaan 2. Pada proses perhitungan menggunakan DFT akan memakan proses komputasi yang sangat banyak dan menghabiskan waktu yang panjang jika jumlah datanya besar. Sehingga untuk membantu proses perhitungan, digunakan algoritma cepat dalam menghitung $\mathrm{TF}$, yaitu dengan algoritma Fast Fourier Transform (FFT). Parameter yang dapat dibentuk pada domain frekuensi salah satunya adalah Mean Power Frekuensi (MPF). MPF merupakan hasil dari penjumlahan bobot magnitudo disetiap frekuensi yang dibagi dengan jumlah magnitudo. MPF dirumuskan seperti pada persamaan 3. Untuk membuat pola MPF sinyal EMG dapat di klasifikasikan dengan jelas, maka tahap pengolahan selanjutnya adalah proses windowing. Dengan tujuan untuk mengurangi efek diskotinuitas sinyal. Dalam proses windowing sinyal EMG digunakan windowing hamming. Proses windowing merupakan hasil perkalian input sinyal EMG dengan fungsi window hamming yang ditunjukkan dengan fungsi windowing, [5].

$$
\begin{aligned}
& \mathrm{F}\{x(t)\}=\mathrm{X}(\omega)=\int_{-\square} x(t) e^{-j \omega t} d t \\
& \operatorname{DFT}\{\mathrm{x}(\mathrm{n})\}=X(k)=\sum_{n=0}^{N-1} x(n) e^{-j \frac{2 \pi}{N} k n} \\
& \mathrm{MPF}=\frac{\sum_{\mathrm{i}=1}^{\frac{\mathrm{N}}{2}} \mathrm{f}(\mathrm{i}) \times \operatorname{mag}(\mathrm{i})}{\sum_{\mathrm{i}=1}^{\frac{\mathrm{N}}{2}} \operatorname{mag}(\mathrm{i})}
\end{aligned}
$$

\section{METODOLOGI}

Penelitian ini dilakukan berdasarkan tahapantahapan penting yang dikerjakan dengan berorientasikan kepada indikator keberhasilan dalam merekam sinyal EMG dan mampu untuk menghasilkan parameterparameter penting dari sinyal EMG tersebut yang dapat diidentifikasi berdasarkan tiap waktu dari otot lengan yang memegang kemudi. Untuk mencapai indikator tersebut, maka tahapan-tahapan dalam penelitian ini tergambar pada Gambar 1. 


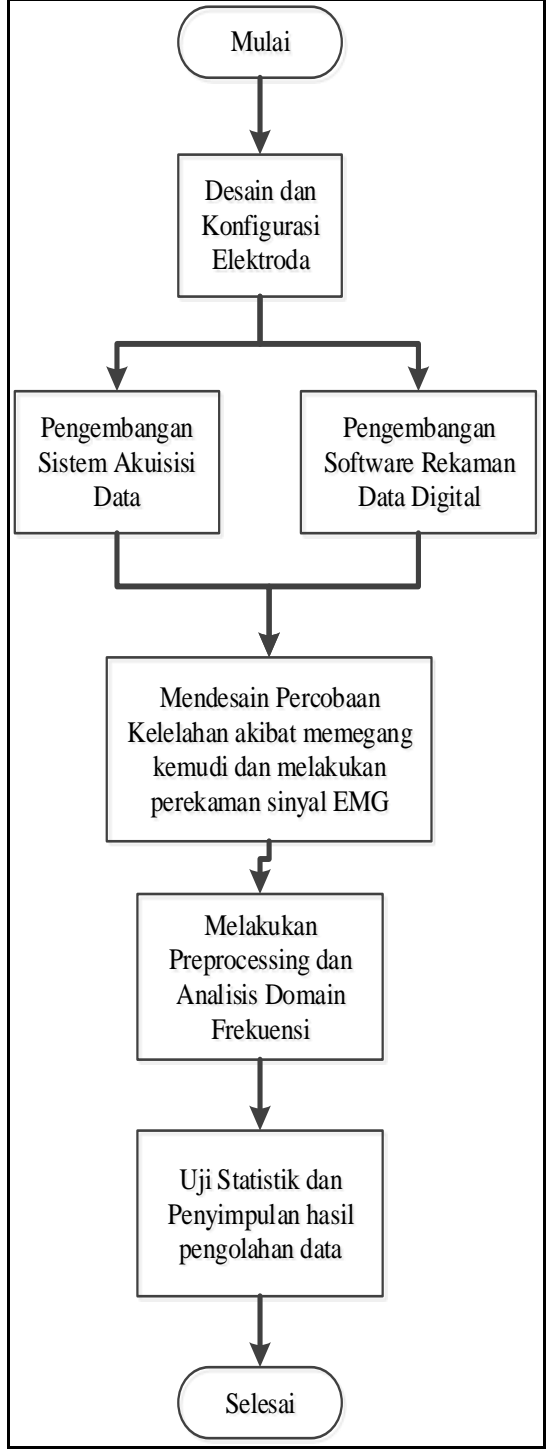

Gambar 1 Tahapan Penelitian

Penelitian memiliki tujuan akhir dan jangka panjang untuk dapat menghasilkan dan menjadi sistem deteksi kelelahan pengemudi berdasarkan informasi kondisi fisiologis pengemudi. Sehingga untuk dapat mewujudkan hal tersebut, maka pada penelitian awal ini, parameter yang menjadi fondasi penting dalam mendukung tujuan tersebut adalah mampu mendapatkan ekstraksi sinyal berdasarkan domain frekuensi. Parameter frekuensi merupakan parameter pengamatan yang dilakukan pada penelitian ini. Hal ini diperoleh berdasarkan studi pendahuluan yang menyatakan bahwa berdasarkan waktu pola sinya EMG berbeda-beda. Untuk dapat menjadikan sesuatu hal yang dapat terukur dengan empiris, maka sinyal EMG tersebut dapat diamati berdasarkan warna dari frekuensinya.

Akuisisi data dilakukan dengan menggunakan frekuensi sampling sebesar $4 \mathrm{KHz}$. Dengan proses filter analog untuk High Pass Filter sebesar $2 \mathrm{KHz}$ dan Low Pass Filter sebesar $500 \mathrm{~Hz}$. Setelah data direkam, pada sinyal dilakukan proses downsampling menjadi $1 \mathrm{KHz}$.
Pada proess digital, dilakukan proses filter Low Pass Filter sebesar $500 \mathrm{~Hz}$. Proses digital selanjutnya adalah dengan melakukan analisis pada domain frekuensi. Untuk melakukannya, diperlukan transformasi fourier dengan menggunakan algoritma fast fourier transform $(f f t)$. Hasil dari transformasi fourier diidentifikasi berdasarkan nilai Mean Power Frequency (MPF). Penelitian ini menggunakan subjek normal laki-laki usia 29 Tahun. Kegiatan pengambilan data dilakukan sebanyak 8 kali.

\section{HASIL DAN PEMBAHASAN}

Kegiatan pengambilan data ditunjukkan seperti pada gambar 2. Pada gambar 2 tersebut, pengemudi melakukan perjalanan dari titik $0 \mathrm{~km}$ di Kota Banjarmasin, dan dilakukan hingga menempuh jarak sejauh 80 km, yakni tepatnya berada di Kota Pelaihari. Kegiatan dilakukan selama 8 kali perjalanan. Perekaman sinyal biologis otot dilakukan ketika baru melakukan perjalanan, yakni di sebelum menempuh jarak $2 \mathrm{~km}$, sinyal yang terekam tersebut digunakan sebagai sinyal saat tidak terjadi kelelahan. Perekaman dilakukan lagi saat mendekati di $\mathrm{km} 80$, yakni pada posisi $\mathrm{km} 78$ sebagai data kelelahan. Adapun contoh sinyal yang berhasil direkam ditunjukkan pada gambar 3 untuk sinyal pengemudi diawal mengemudi dan pada gambar 4 untuk sinyal kelelahan setelah mengemudi sejauh $80 \mathrm{~km}$.

Sinyal biologis otot yang diperoleh, baik itu sebelum berkendara maupun setelah berkendara dilakukan pengekstraksian ciri berdasarkan domain frekuensi. Hal ini dilakukan guna memperoleh dan mendapatkan ciri dari dua kondisi tersebut. Untuk dapat melakukannya, digunakan transformasi fourier untuk mengkonversi kedalam domain frekuensi. Pengkonversian menggunakan algoritma fast fourier transform (FFT). Selanjutnya setelah dikonversi kedalam domain frekuensi, maka dilakukan perhitungan terhadap Mean Power Frekuensi (MPF). MPF merupakan hasil dari penjumlahan bobot magnitudo disetiap frekuensi yang dibagi dengan jumlah magnitudo. MPF dapat mencerminkan difrekuensi mana sinyal tersebut dominan. Adapun hasil dari perhitungan MPF ditunjukkan pada Tabel 1. Sedangkan spektrum frekuensi dari kedua sinyal biologis otot tersebut, ditunjukkan pada Gambar 5 dan Gambar 6. 


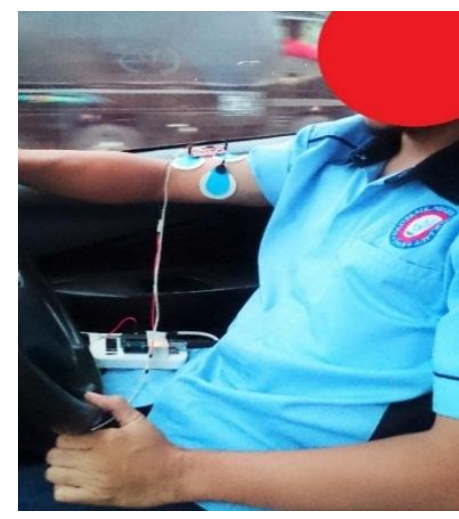

Gambar 2 Aktifitas Pengambilan Data Sinyal Biologis Otot Pengemudi

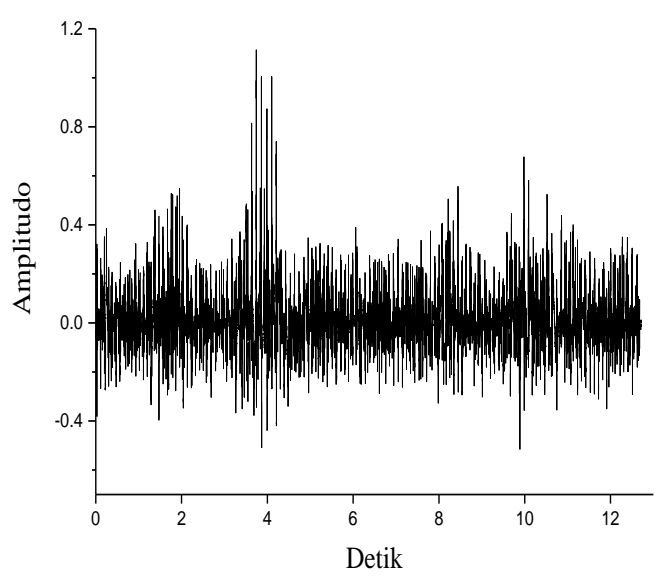

Gambar 3 Sinyal Biologis Otot Pengemudi Pada Awal Berkendara

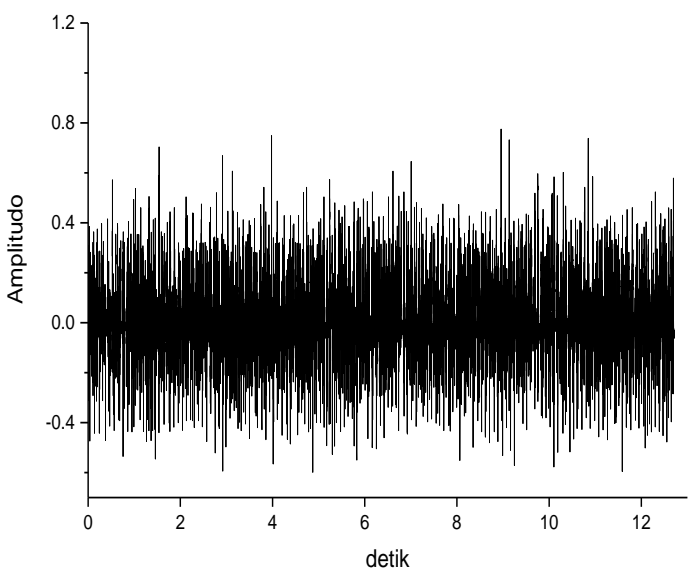

Gambar 4 Sinyal Biologis Otot Pengemudi Setelah Berkendara

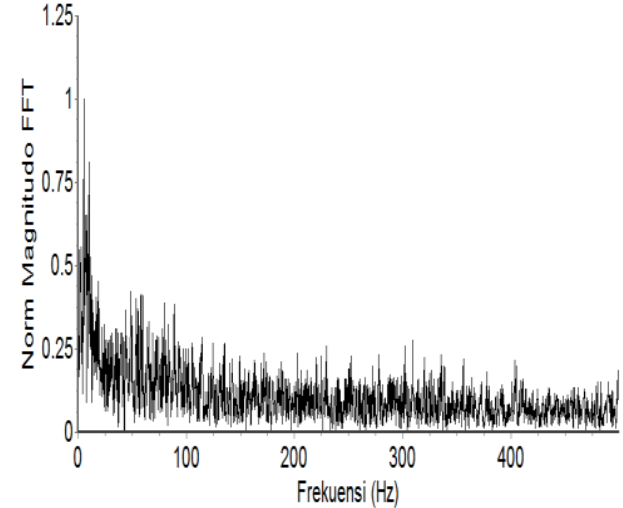

Gambar 5 Spektrum Frekuensi Sinyal Biologis Otot Kondisi Awal Berkendara

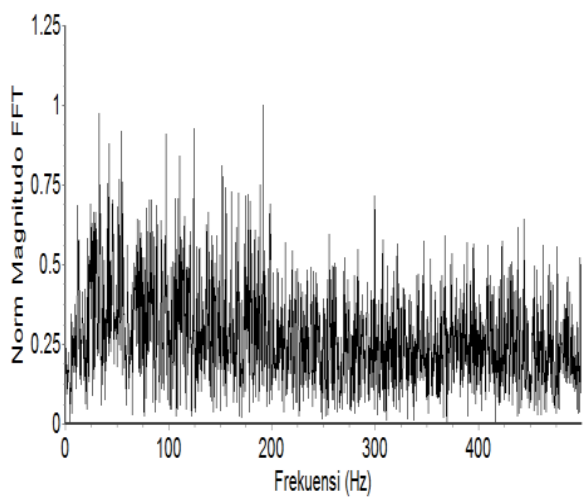

Gambar 6 Spektrum Frekuensi Sinyal Biologis Otot Kondisi Setelah Berkendara

Tabel 1 Perbandingan nilai MPF saat awal berkendara dengan setelah berkendara.

\begin{tabular}{|c|c|c|}
\hline $\begin{array}{c}\text { Percobaan } \\
\text { Ke- }\end{array}$ & \multicolumn{2}{|c|}{ Mean Power Frekuensi (Hz) } \\
\cline { 2 - 3 } $\mathbf{1}$ & Awal & Akhir \\
\hline $\mathbf{2}$ & 25,6 & 33,5 \\
\hline $\mathbf{3}$ & 26,5 & 33,3 \\
\hline $\mathbf{4}$ & 23,3 & 32,3 \\
\hline $\mathbf{5}$ & 27,4 & 32,8 \\
\hline $\mathbf{6}$ & 24,4 & 33,2 \\
\hline $\mathbf{7}$ & 24,0 & 33,7 \\
\hline $\mathbf{8}$ & 24,6 & 34,0 \\
\hline Rata-rata & 26,4 & 33,9 \\
\hline $\begin{array}{c}\text { Standar } \\
\text { Deviasi }\end{array}$ & $\mathbf{2 5 , 2}$ & $\mathbf{3 3 , 3}$ \\
\hline
\end{tabular}

Sinyal biologis otot yang direkam merupakan hasil dari representasi aktifitas elektris yang terjadi saat konstraksi otot. Sinyal tersebut direkam dengan menggunakan surface EMG di bagian lengan sebelah kanan. Elektroda yang menempel sebelah kanan 
dihubungkan dengan penguat instrumentasi dan digitalisasi melalui unit pemproses sinyal untuk dapat disimpan kedalam komputer. Akuisisi data dilakukan dengan menggunakan frekuensi sampling sebesar 4 KHz. Dengan proses filter analog untuk High Pass Filter sebesar $2 \mathrm{KHz}$ dan Low Pass Filter sebesar $500 \mathrm{~Hz}$. Setelah data direkam, pada sinyal dilakukan proses downsampling menjadi $1 \mathrm{KHz}$. Pada proess digital, dilakukan proses filter Low Pass Filter sebesar $500 \mathrm{~Hz}$. Proses digital selanjutnya adalah dengan melakukan analisis pada domain frekuensi. Untuk melakukannya, diperlukan transformasi fourier dengan menggunakan algoritma fast fourier transform (fft). Hasil dari transformasi fourier diidentifikasi berdasarkan nilai Mean Power Frequency (MPF). Penelitian ini menggunakan subjek normal laki-laki usia 29 Tahun. Kegiatan pengambilan data dilakukan sebanyak 8 kali.

Berdasarkan hasil perhitungan MPF diperoleh nilai untuk saat awal berkendara nilai rata-rata MPF nya adalah sebesar 25,2 $\mathrm{Hz}$ sedangkan pada akhir berkendara bernilai sebesar $33,3 \mathrm{~Hz}$. Nilai MPF merupakan refresentasi dari nilai frekuensi mana yang lebih dominan pada spektrum frekuensi sinyal, tentu hal ini mengindikasikan nilai frekuensi untuk setiap kondisi pengemudi, yakni saat awal berkendara nilai frekuensi yang lebih dominan adalah $25,2 \mathrm{~Hz}$ atau lebih rendah dari setelah berkendara. Dengan hasil ini dapat tergambarkan kondisi pengemudi yakni pada saat awal mengemudi dan tidak terjadi kelelahan maka nilai frekuensi yang diminan cenderung lebih kecil jika dibandingkan dengan setelah berkendara atau saat kelelahan.

Dengan adanya perbedaan yang jelas, maka proses penetuan kelelahan dapat ditentukan berdasarkan sinyal biologis otot berdasarkan parameter frekuensi sinyalnya. Untuk upaya dalam melakukan pendalaman analisis terhadap kelelahan dan untuk dapat menetuan tingakatan kelelahan maka penelitian ini dapat dilanjutkan dengan melakukan penambahan input parameter sinyal biologis lainnya seperti detak jantung dan pola pernapasan pengemudi.

\section{KESIMPULAN}

Penelitian ini telah diselesaikan dari tahapan perancangan sisi hardware dan software serta pada sisi analisis. Pada sisi hardware telah dirancang alat perekam sinyal biologis EMG yang diletakkan pada bagian lengan pengemudi. Sedangkan pada sisi software telah dikembangkan program antar muka yang akan merekem sinyal biologis EMG mejadi data digital, dan sinyal telah dianalisis lebih lanjut menggunakan analisis domain frekuensi hingga menghitung nilai MPF nya. Hasil yang diperoleh yaitu pada awal berkendara atau saat belum terjadi kelelahan otot nilai MPF yang diperoleh dengan rata-rata sebesar $25,2 \mathrm{~Hz}$ sedangkan untuk setelah berkendara atau saat terjadi kelelahan nilai rata-rata MPF nya adalah sebesar $33,3 \mathrm{~Hz}$. Dengan adanya perbedaan ini, maka dapat disimpulkan bahwa pengemudi yang kelelahan memiliki nilai MPF yang cenderung lebih tinggi daripada sebelum berkendara atau tidak terjadi kelelahan.

\section{UCAPAN TERIMA KASIH}

Penelitian ini dibiaya oleh dana riset dari Kementrian Riset Teknologi dan Pendidikan Tinggi Negara Republik Indonesia pada tahun 2016

\section{DAFTAR PUSTAKA}

[1] Enoka. Roger M, Duchateau. jacques, 2008, "Muscle fatigue: what, why and how it influences muscle function", The Journal of Physiology, vol 586, no. 01, pp. 11-23.

[2] Martini. Frederic H, Nath. Judi L, Bartholomew. Edwin F, 2014, "Fundamentals of Anatomy \& Physiology 10th", Pearson.

[3] Webster. John G, 2010, "Medical Instrumentation application and design fourth edition", Wiley.

[4] Zawawi. T.N.S.T, Abdullah. A.R, Shair. E.F, Halim. I, Rawaida.O, 2013,"Electromyography Signal Analysis Using Spectrogram", IEEE Student Conference on Research and Development (SCOReD) 16-17 Desember 2013 Putrajaya Malaysia. pp. 319 - 324.

[5] Dantas. Jose L, Camata. Thiago V, Brunetto. Maria A.O.C, Moraes. Antonio C, Abrao. Taufik, Altimari. Leandro R, 2010, "Fourier and Wavelet Spectral Analysis of EMG signals in Isometric and Dynamic Maximal Effort Exercise", 32nd Annual International Conference of the IEEE EMBS, pp.5979-5982. 